American Journal of Environmental Sciences 6 (3): 212-218, 2010

ISSN 1553-345X

(C) 2010 Science Publications

\title{
Criteria and Indicators for Sustainable Forest Management in Malaysia
}

\author{
Rabiul Islam, Chamhuri Siwar, Shaharuddin Mohamad Ismail and Nurul Hidayah Chamhuri \\ Institute for Environment and Development (LESTARI), University Kebangsaan Malaysia, \\ 43600 UKM Bangi, Darul Ehsan, Selangor, Malaysia
}

\begin{abstract}
Problem statement: This study investigated the timber certification of sustainable forest management and the criteria and indicators for sustainable forest management. Approach: Sustainable forest management is an important role in the forestry sector and takes a major player in Malaysia's sustainable development. It is a management regime that integrates and balances social, economic, ecological, cultural and spiritual needs to present and future generations. Results: We analyzed the pillars of sustainable forest management, criteria, indicators, activities and standards of performance for sustainable forest management in Malaysia. Conclusion: The aim of this study was to highlight and clarify the impacts of trade and environment on sustainable forest management in Malaysia.
\end{abstract}

Key words: Sustainable forest management, criteria and indicators, timber certification

\section{INTRODUCTION}

Sustainable Forest Management (SFM) is the way of management in which growth exceeds timber harvest, now also encompasses economics, environmental and social qualities that contribute to the sustainability of forest dependent communities and ecosystems as well as the forest itself. Malaysia has a plan more environmentally-friendly and responsible business practices. This will help reduce operating costs in the long-run and is a wise investment in the future, safeguarding the natural resources depending on corporations and communities. For example, local corporations in forest industries are joining WWF's Global Forest and Trade Network. They are targeting European and US markets, where consumers are increasingly demanding wood products from sustainably managed forests (WWF-Malaysia, 2008).

According to International Tropical Timber Organization (ITTO, 1992) sustainable forest management is defined as the process of managing permanent forest land to achieve one or more clearly specified objectives of management with regard to the production of a continuous flow of desired forest products and services without undue reduction of its inherent values and future productivity and without undue undesirable effects on the physical and social environment while FAO (1993) defines it as one which ensures that the values derived from forest meet present day needs while at the same time ensuring their continued availability and utilization to long-term development needs.

Sustainable Forest Management (SFM) is impossible to achieve if a country does not have a management system. In this regard, the use of more systematic approach in managing the forests in Peninsular Malaysia began in 1901 when the first forest officer was appointed (Ismail, 1996). Since then, forest management practices in Peninsular Malaysia had been subjected to constant review and refinement so as to ensure their suitability in achieving forest renewal and sustained yield.

Sustainable forest management is a part of sustainable development. Rabiul et al. (2010) stated the impacts of trade and environment on sustainable development. They also discussed their paper about the development of market access, trade barriers, trade liberalization, environmental degradation and pollution, sustainable forest management and sustainable development.

Kamaruzaman and Dahlan (2008) state the sustainable forest management practices and environmental protection in Malaysia. In response to the needs to promote SFM, the Forestry Department Peninsular Malaysia has produced the Malaysian Criteria and Indicators (MC \& I) that clarify major activities that have to be complied with sustainable basis. To ensure that the forest is better conserved, the annual coupe in Peninsular Malaysia has been scaled down for each Malaysian Plan starting from the 4th

Corresponding Author: Rabiul Islam, Institute for Environment and Development (LESTARI),

University Kebangsaan Malaysia, 43600 UKM Bangi, Darul Ehsan, Selangor, Malaysia

Tel: +603-89214161 Fax: +60389255104 
Am. J. Environ. Sci., 6 (3): 212-218, 2010

Malaysia Plan (1981-1985) of 74,869-36,940 ha year ${ }^{-1}$ under the 9th Malaysia Plan (2006-2010).

Rahim et al. (2009a) describe the sustainable forest management and west Malaysian sawntimber supply analysis. The calculation of the allowable cut was an important element of forest management. It is expressed in term of forest area of wood volume to be harvested. The goal was to obtain a sustainable yield of the best possible yield. Mohd Shahwahid and Awang Noor (2002) revealed that the annual coupe was lower than the official approved annual coupe by $34 \%$. In fact, in Peninsular Malaysia, annual coupes have been steadily declining and this is part of the conservation strategy to ensure sustainable timber production. Hence, the sustainable yield has been one of the basic views of forest management for a considerable length of time. Initially, the only goal or at least the main goal in mind of forester was usually wood production.

Rahim et al. (2009b) represents the sustainable forest management practices and west Malaysian log market. The sustainable management definition and objectives required maintenance of the forest stand regeneration not only for timber production, also for environmental stability, biodiversity conservation, but recreational values preservation and other forest products and forest components conservation. Motivated by ITTO target, National Committee Sustainable Forest Management was established in 1994 under the Ministry of Primary Industries. This committee has formulated a total of 92 activities, based on 5 criteria and 27 indicators to implement the ITTO criteria at the national level (Thang, 2002). SFM has led to greater planning and monitoring of the environment. In term of economic, there are indications to incur incremental costs.

Rabiul and Chamhuri (2010) addressed the trade and environment in the forestry sector towards sustainable forest management. They discussed their paper about the trends in production for different types of forestry wood products. With regards to SFM practices, Schwarzbauer and Rametsteiner (2001) have analyzed the potential impacts of SFM certification on forest products markets using a simulation model of the Western European forest sector. The empirical evidence shows that rather modest changes are to be expected from SFM certification in forest products markets. The market impact of timber supply reduction from certified forest would be more distinct than the impact of chain of custody costs. That means, a decrease of harvesting levels in certified forest will affect forest products markets more than the increase costs related to the installation and maintenance of SFM certification in the forest sector.
The purpose of this study is to obtain the timber certification, criteria and indicators for sustainable forest management and the impacts of trade and environment on sustainable forest management in Malaysia.

\section{MATERIALS AND METHODS}

Data attainment: The study is conducted in University Kebangsaan Malaysia, Bangi since July, 2008 to November, 2009. The data for analysis is perceived from secondary sources in Malaysia. The significant manipulations for acquired data are sustainable forest management, timber certification and criteria and indicators for sustainable forest management. The corresponding outcomes are demonstrated from the analysis of collected data.

Sustainable forest management: Sustainable forest management implies the sustainable utilization of forest resources for the benefit of communities and states. The concept not only aims to maintain the value of forest resources, it also has a huge potential for creating employment, income and wealth for the populations and states concerned. The sustainable forest management programme seeks to improve the management of natural tropical forests by increasing the adoption of sustainable forest management practices by forest managers from industries to communities. Good forest management can both reduce the negative impacts of timber harvesting on other forest resources and services and increase yields of desired products and services from a given area of forest.

Criteria and indicators for sustainable forest management in Malaysia: Sustainable forest management is considered as one of the most important contributions which the forestry sector can make to the sustainable development objectives of any nation, particularly those richly endowed with forest. The UNCED, held in Rio de Janeiro in 1992, set the guiding principles for sustainable forest management as a contribution towards sustainable development.

MTCC (2001) states that the Malaysian Criteria, Indicators, activities and Standards of Performance for Forest Management Certification (MC \& I) will be used for assessing forest management practices in the Permanent Forest Estate (PFE) at Forest Management Unit (FMU) level for the purpose of certification.

Wolfslehner et al. (2005) addresses the application of the analytic network process in multi-criteria analysis of sustainable forest management. The demand to assess forest-management regimes and alternatives in 
regards to their specific benefits and to sustainability in general has lead to the use of Criteria and Indicators $(\mathrm{C}$ \& I) (Prabhu et al., 1996; Van Bueren and Blom, 1997). Criteria are the essential elements against which sustainability is assessed to the productive, protective and social roles of forests and forest ecosystems. Each criterion relates to a key element of sustainability and may be described by one or more indicators. Indicators are parameters which can be measured and correspond to a particular criterion (Prabhu et al., 1999). C \& Iapproaches appear to be highly capable of measuring aspects of SFM at national, regional and forest management unit levels.

Regional level criteria and indicators: Criteria and indicators for sustainable forest management have become an important issue in many countries around the world. At present, many countries are taking part the sets of criteria in all nine processes that SFM comprises the following thematic areas:

- Extent of forest resources

- Biological diversity

- Forest health and vitality

- Protective functions of forests

- Productive functions of forests

- Socio-economic functions

- Legal policy and institutional framework (FAO, 2005)

National level criteria and indicators: National level criteria and indicators help decision makers, including planners and policy makers, to define what makes up SFM and to establish guidelines and monitor trends in the sustainability of the goods and services being provided by a nation's forests.

Major criteria and indicator processes and initiatives:

- International Tropical Timber Organization (ITTO)

- Pan-European

- Montreal

- Tarapoto

- Dry Zone Africa

- Near East

Forest management unit level criteria and indicators: Forest management unit level criteria and indicators have been increasingly developed and implemented to complement national criteria. The forest management unit level indicators depend on local, often site-specific, environmental factors such as forest type and topography, local economic and social considerations and priorities. The criteria at forest management unit level are likely to be identical or very similar to those defined at national level, although they are more flexible. Thus, they must be mutually compatible to help ensure complementarily over the country.

C \& I-approaches is that it can be used to collect and report information within a system, which is usually characterized by a lack of knowledge, uncertainties and missing information about impacts, dependencies and feedbacks (Rametsteiner, 2001; Brang et al., 2002). C \& I has become a common approach to assess the aspects of SFM. Among these approaches, Multi-Criteria Analysis (MCA) techniques have been adapted to structure and implement the $\mathrm{C} \&$ I-based assessment of SFM (Varma et al., 2000; Bousson, 2001; Mendoza and Prabhu, 2003). Ecologically and environmentally sound forest conservation and management practices have been developed to ensure that the forest resources are managed for the sustainable timber production, ensuring climatic stability and ecological balance, safeguarding of water supply and environmental quality and the conservation of biological diversity. Today, Malaysia, as a member of the International Tropical Timber Organization (ITTO) which is fully committed to ITTO's objectives, is striving towards the achievement of forest management that is environmentally responsible, socially beneficial and economically viable. ITTO has developed a set of key Criteria and Indicators (C \& I) for the sustainable management of tropical forests (ITTO, 2005).

Timber certification: Baharuddin and Simula (1994) states that timber certification is a process which results in a written statement (a certificate) attesting to the origin of wood raw material and its status the following validation by an independent third party. Certification is designed to allow participants to measure their forest management practices against standards and to demonstrate compliance with those standards. Timber certification typically includes two main components: certification of sustainability of forest management and product certification. Certification of forest management covers forest inventory, management planning, silvi-culture, harvesting, road construction and other related activities, as well as the environmental, economic and social impacts of forest activities. In product certification, round-wood and processed timber products are traced through the successive phases of the supply chain. Certification of 
forest management thus takes place in the country of origin; product certification covers the supply chain of domestic and export markets.

Kamaruzaman and Dahlan (2008) have stated that Malaysia is a producer member country of the International Tropical Timber Organization (ITTO) which is committed to achieve sustainable forest management of sustainable development. Developing countries follow timber certification in order to protect domestic timber products. Today, timber certification is the slogan in forest harvesting. Malaysia timber certification began in 1994 in stages. The Malaysian Timber Certification Council (MTCC) is an independent organization established in 1998 to develop and operate the Malaysian Timber Certification Scheme (MTCS) in order to provide independent assessments of forest management practices in Malaysia as well as to meet the demand for certified timber products. Timber certification is a market-linked tool to promote and encourage sustainable forest management as well as to provide an assurance to buyers that the timber products they buy come from sustainably managed forests. The Malaysian Criteria, Indicators, activities and Standards of Performance for Forest Management Certification (MC \& I) is the standard that will be used for assessing forest management practices in the Permanent Forest Estate (PFE) at Forest Management Unit (FMU) level for the purpose of certification.

Thang (2003) states that timber certification can be defined as a process which entails an independent assessment of a forest management operation, according to specific economic, social, environmental and ecological criteria, indicators, activities and management specifications or standards of performance. Forest Management Unit is defined as an area of forest land that is managed by an organizational entity which decides on and subsequently implements forest activities to ensure the economic, ecological, biological and socio-cultural sustainability of the area. It addressed the issues of forest inventory, management planning, silvi-culture, harvesting, forest road construction and other related forest management operations.

MTCC addresses the eight forest management units in Malaysia, namely the states of Johor, Kedah, Negeri Sembilan, Pahang, Perak, Selangor, Terengganu and Kelantan. They are covering $4.7 \mathrm{~m}$ ha of the PRFs in Peninsular Malaysia which are certified using the set of Malaysian Criteria and Indicators (MTCC, 2001).

The standard currently being used for assessing Forest Management Units (FMUs) is the Malaysian Criteria, Indicators, Activities and Standards of
Performance for Forest Management Certification (MC \& I). The MC \& I are based on the 1998 ITTO Criteria and Indicators for Sustainable Management of Natural Tropical Forests. It contains the key elements for sustainable forest management covering economic, social, environmental and conservational aspects and incorporates the corresponding standards of performance for Sabah, Sarawak and Peninsular Malaysia identified during the regional and national level consultations held in 1999.

\section{RESULTS AND DISCUSSION}

Sustainable Forest Management (SFM) is the process of managing forest land to achieve one or more clearly specified objectives of management without undue reduction of its inherent values and future productivity or undesirable effects on the economic, social and environment (ITTO, 1992) and integrates and balances social, economic, ecological, cultural and spiritual needs to present and future generations (United Nations, 1992). There are three pillars of SFM include the Fig. 1.

Economic: The capacity of the forests to attract investment and support economically viable forest uses in the present and the future is undiminished. The forest is not used beyond its long-term capacity for production of wood and non-wood forest products.

Social: There are a variety of pillars include social such as:

- The rights of indigenous peoples and local communities are respected and protected

- $\quad$ Forest workers are healthy, safe and their rights are protected (e.g., freedom of association, right to bargain, child labor, forced labor, equal remuneration and non-discrimination)

- Local communities, including indigenous peoples, benefit economically from forest management

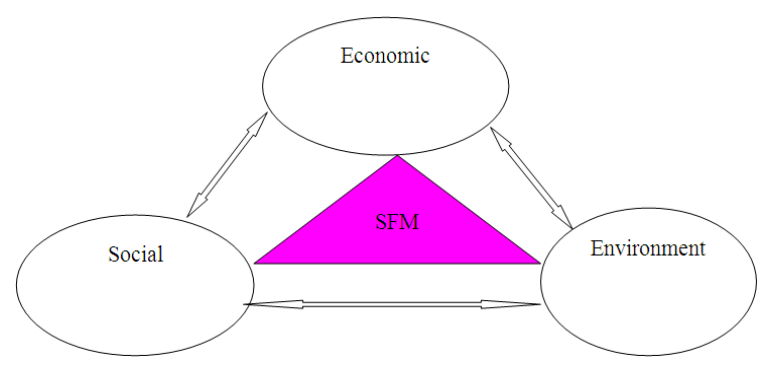

Fig. 1: Pillars of sustainable forest management 
Am. J. Environ. Sci., 6 (3): 212-218, 2010

Table 1: Criteria, indicator, activities and standards of performance for sustainable forest management at the national level in the MC \& I

\begin{tabular}{lccc}
\hline Criteria & Indicators & Activities & Standards of performance+ \\
\hline Enabling condition for sustainable forest management & 9 & 31 & 20 \\
Forest resource security & 5 & 22 & 17 \\
Forest ecosystem health and condition & 5 & 20 & 13 \\
Flow of forest produce & 12 & 37 & 31 \\
Biological diversity & 8 & 25 & 22 \\
Soil and water & 9 & 26 & 29 \\
Economics, social and cultural aspects & 16 & 39 & 38 \\
Total 7 & 64 & 200 & 170 \\
\hline
\end{tabular}

+: For peninsular Malaysia only

Table 2: Criteria, indicators, activities and standards of performance for sustainable forest management at the forest management unit level in the MC \& I

\begin{tabular}{lcrr}
\hline Criteria & Indicators & Activities & Standards of performance+ \\
\hline Enabling condition for sustainable forest management & 8 & 26 & 17 \\
Forest resource security & 5 & 22 & 17 \\
Forest ecosystem health and condition & 3 & 12 & 37 \\
Flow of forest produce & 12 & 21 & 31 \\
Biological diversity & 7 & 26 & 29 \\
Soil and water & 9 & 27 & 29 \\
Economics, social and cultural aspects & 12 & 171 & 150 \\
Total 7 & 56 & & \\
\hline
\end{tabular}

+: For peninsular Malaysia only

Table 3: Relationship and number of criteria, indicators, activities and standards of performance formulated at different management levels in the MC \& I

\begin{tabular}{llll}
\hline Management levels & Criteria & Indicators & Activities \\
\hline National level (SFM) \# & 7 & 64 & 200 \\
FMU\# level (SFM) & 7 & 56 & $171^{*}$ \\
FMU level (forest management certification) & 7 & 53 & $162++$ \\
\hline
\end{tabular}

+: For Peninsular Malaysia only; (SFM) \#: Sustainable Forest Management; FMU: Forest Management Unit; *: 86\% are identical to those formulated at the National level; **: $88 \%$ are identical to those formulated at the National level; ++: A subset of activities/standards of performance taken from those formulated at the FMU level (SFM)

- $\quad$ Sites of religious, spiritual, archaeological, historic as well as of aesthetic and recreational value are preserved

Environmental: Forest use protects biodiversity (ecosystems, species, genes and ecological processes) and the capacity to maintain ecosystem processes and services such as watershed protection, pollination, protection against mudslides, aesthetic beauty and carbon storage.

The economic pillar is a suitable mix of wood products and non-wood products (plants and animals), that does not diminish the productive capacity of the forest. Social pillars include respect for labor and indigenous rights, the health and safety of forest workers, sharing of economic benefits and protection of sites of spiritual or historic value. Environmental pillars can include soil protection, biodiversity, maintenance of air and water quality and aesthetics. The appropriate balance of these pillars will vary among regions and contexts.

MTCC harmonized through meetings with various stakeholders. The MTCC (2001) contain key elements for SFM covering economic, social and environmental aspects. The MC \& I contains 7 criteria, 64 indicators,
200 activities and 170 standards of performance were formulated at the national level (Table 1); while 7 criteria, 56 indicators, 171 activities and 150 standards of performance were formulated for assessing sustainable forest management at the forest management unit (Table 2). In Malaysia, the criteria, indicators, activities and management specifications at the national level would be used for reporting progress towards achieving sustainable forest management and in particular, the ITTO Year 2000 Objective (Table 3). Those formulated at the forest management unit level would be used by the Forestry Departments to monitor and assess progress in sustainable forest management at the state level including forest certification by independent third party assessors.

\section{CONCLUSION}

Malaysia is fully aware of the need to manage the forest effectively from single use of sustained supply of timber to multiple-use of forestry including maintaining of the environmental stability. Malaysia, like many countries around the world, is working hard to find ways to use its forests for community benefit within the constraints imposed by ecological processes and 
ensuring that future options are not foreclosed. Over the last several years, C \& I have emerged as one of the most powerful forest management tools designed to promote SFM. Criteria and indicators developed for application will be reviewed and refined periodically to reflect new concepts of sustainable forest management based on the evolving knowledge about the functioning of forest ecosystem, anthropogenic intervention on the forests whether planned or unplanned and the changing needs of society for forest goods and services. The level of management will be refined once the current silvicultural management systems are further developed for application at a lower management level, perhaps at the forest district level, forest reserve level or even at the compartment level. Malaysia continues to strongly support international efforts to promote and ensure sustainability in forest management. The implementation of timber certification will continue to be actively pursued to ensure market access of Malaysian timber product, especially in environmentally sensitive markets. Timber certification is very essential in the following reasons:

- To restrict the importation of tropical timber products due to illegal logging and the associated trade in illegally sourced timber products

- The measures to implement public timber procurement policies

- The Forest Law Enforcement, Governance and Trade (FLEGT) action plan which is being implemented by the EU, Voluntary Partnership Agreements (VPAs)

\section{ACKNOWLEDGEMENT}

Financial assistance provided by the Research University Grant (GUP), Institute for Environment and Development, University Kebangsaan Malaysia is gratefully acknowledged.

\section{REFERENCES}

Baharuddin, H.G. and M. Simula, 1994. Certification Schemes of All Types of Timber. ITTO.

Bousson, E., 2001. Development of a Multicriteria Decision Support System Adapted to Multiple-Use Forest Management: Application to Forest Management at the Management Unit Level in Southern Belgium. In: Criteria and Indicators for Sustainable Forest Management at the Forest Management Unit Level, Franc, A., O. Laroussinie and T. Karjalainen (Eds.). European Forest Institute, Joensuu, Finland, pp: 14.
Brang, P., B. Courbaud, A. Fischer, I. Kissling-Naf, D. Pettenella et al., 2002. Developing indicators for the sustainable management of mountain forests using a modeling approach. For. Policy Econ., 4: 113-123.

FAO., 1993. Forest Resources assessment 1990: Tropical Countries. FAO Forestry Paper 112, Rome, Italy.

FAO., 2005. State of the World's Forest 2005. FAO, Rome, Italy.

Ismail, A., 1996. Sustainable forest management in Malaysia-the way forward. Proceeding of the Thailand Environment Institute Annual Conference, July 9-9, Bangkok, Thailand, pp: 26.

ITTO., 1992. Criteria for the Measurement of Sustainable Tropical Forest Management. ITTO., Yokohama, Japan, pp: 5.

ITTO., 2005. Revised ITTO Criteria and Indicators for Sustainable Management of Tropical Forests Including Reporting Format. ITTO., ISBN: 4902045-20-6, pp: 40.

Kamaruzaman, J. and H. Dahlan, 2008. Sustainable Forest management practices and environmental protection in Malaysia. WSEAS Trans. Environ. Dev., 3: 191-199.

Mendoza, G.A. and R. Prabhu, 2003. Qualitative multicriteria approaches to assessing indicators of sustainable forest resource management. For. Ecol. Manage., 174: 329-343.

Mohd Shahwahid, H.O. and A.G. Awang Noor, 2002. Responses of timber Concessionaires to Selected Policy Instrument. International Development Research Center, Singapore.

MTCC., 2001. Malaysian Criteria, Indicators, Activities and Standards of Performance for Forest Management Certification.

Prabhu R., C. Colfer, P. Venkateswarlu, L.C. Tan, R. Soekmadi and E. Wollenberg, 1996. Testing Criteria and Indicators for the Sustainable Management of Forests. Phase I. CIFOR Special Publication, Jakarta.

Prabhu, R., C.J.P. Colfer and R.G. Dudley, 1999. Guidelines for Developing, Testing and Selecting Criteria and Indicators for Sustainable Forest Management. Center for International Forestry Research, Jakarta.

Rabiul, I. and S. Chamhuri, 2010. Trade and Environment in the Forestry Sector: Towards Sustainable Forest Management. Asian J. Sci. Res., 3: 1-17.

Rabiul, I., S. Chamhuri and M.I. Shaharuddin, 2010. Impacts of trade and environment on sustainable development. Am. J. Environ. Sci., 6: 11-19. 
Rahim, A., A. Samad and M.S.H. Othman, 2009a. Sustainable forest management and west Malaysian Sawn timber supply analysis. J. Sustain. Dev., 2: 58-64.

Rahim, A., A. Samad, Z.M. Ashhari and M.S.H. Othman, 2009b. Sustainable forest management practices and west Malaysian log market. Asian Soc. Sci., 5: 69-76.

Rametsteiner, E., 2001. SFM Indicators as Tools in Political and Economic Context: Actual and Potential Roles. In: Criteria and Indicators for Sustainable Forest Management, Raison, R.J., A.G. Brown and D.W. Flinn (Eds.). CABI Publishing, Wallingford, UK, pp: 24.

Schwarzbauer, P. and E. Rametsteiner, 2001. The impact of SFM-certification on forest product markets in Western Europe-an analysis using a forest sector simulation model. For. Policy Econ., 2: 241-256.

Thang, H.C., 2002. Towards achieving sustainable forest management in Peninsular Malaysia. Proceeding of the National Seminar on Practicing Sustainable Forest Management: Lessons Learned and Future Challenges, Aug. 20-22, Kota Kinabalu, Sabah, Malaysia.
Thang, H.C., 2003. Development and Application of Criteria and Indicators for Sustainable Forest Management in Malaysia. Proceeding of the Attachment Training of Bhutanese Foresters in Malaysia, Oct. 11-31, Kuala Lumpur, Malaysia.

United Nations, 1992. United Nations Conference on Environment and Development. Agenda 21.

Van Bueren, E.M.L. and E.M. Blom, 1997. Hierarchical Framework for the Formulation of Sustainable Forest Management Standards, Principles, Criteria, Indicators. The Tropenbos Foundation, pp: 82.

Varma, V.K., I. Ferguson and I. Wild, 2000. Decision support system for sustainable forest management. For. Ecol. Manage., 128: 49-55.

Wolfslehner, B., H. Vacik and M.J. Lexer, 2005. Application of the analytic network process in multi-criteria analysis of sustainable forest management. For. Ecol. Manage., 207: 157-170. DOI: $10.1016 /$ j.foreco.2004.10.025

WWF-Malaysia, 2008. Annual Review. World Wide Fund for Nature, Malaysia. 